cellular, septate, branched, developing numerous dark reddish-brown resting spores. Young spores are at first thin-walled, hyaline and pyriform, and turn deep brown and warty as they mature. The mature spores are reddish-brown, globose-oval, thick-walled, covered with pyramidal warts, measuring $22 \cdot 5-32 \cdot 5 \mu$ (F.ig. 2). Studies on germination of resting spores and other cultural studies are in progress.

As regards the identity of the pathogen, the fungus is a species of Protomycopsis, which is indicated by the warty nature of its exospore and other characters. Synchytrium phaseoli Patel, Kulkarni and Dhande was reported from Jalagaon, Bombay State, by Patel et al. ${ }^{1}$, as inciting leaf spots on mung beans. A portion of the type material was examined by us through the kindness of Dr. M. K. Patel. The results suggest that the fungus reported as $S$. phaseoli is identical with the fungus found by us. The intercellular hyphæ and resting spores distributed in the spaces indicate that it bears no relation to Synchytrium. The name Synchytrium phaseoli Weston precedes $S$. phaseoli Patel et al., consequently the Protomycopsis species under study is designated $P$. patelii Pavgi and Thirumalachar nom. nov. in honour of Dr. M. K. Patel, who has contributed greatly to our knowledge of Indian fungi.

A detailed account will be published elsewhere.

M. S. PavaI

M. J. ThirumalachaR

College of Agriculture,

Banaras Hindu University, and

Malleshwaram, Bangalore.

${ }^{1}$ Patel, M. K.., Kulkarni, Y. S., and Dhande, G. W. Curr. Sci., 18, $171(1949)$.

\section{Preservation of the Virus of Tomato Spotted Wilt in Dried Plant Material}

IT is difficult to obtain accurate information about, the properties of viruses which lose their infectivity in vitro too quickly. Tomato spotted wilt virus is one of these, and investigations on it are further limited by the fact that it is inactivated at comparatively low temperatures $\left(35^{\circ} \mathrm{C}\right.$. $)$. The in vitro life of tomato spotted wilt virus was reported by Bald and Samuel ${ }^{1}$ to be about four hours in, undiluted expressed juice held at room temperature. Subsequent work by Best and Samuel ${ }^{2}$ and by Best ${ }^{3}$ showed that the factors causing inactivation were the $p^{\prime} \mathrm{H}$ value of the juice and a tyrosinase catalysed oxidation, and that by controlling the $p \mathrm{H}$ value and redox potential of the medium ${ }^{4}$ the virus could be maintained infective in solution for thirty-five days at $2^{\circ} \mathrm{C}$.

Slow drying of infective plant tissue near the freezing point was not successful.

Transferring freshly harvested infective material to a 'deep-freeze' at $-20^{\circ} \mathrm{C}$. met with partial suocess : strain $^{5} A$ survived for thirty-two days but not for seventy-four days, and strain $E$ remained infective for thirty-six days but not for seventy-eight days.

The most successful method yet tried is to freezedry tissue and store it at a low temperature. Tomato leaflets infected with strain $A$ and tissue of $N$. glutinosa infected with strain $E$ were put into a deep freeze at $-20^{\circ} \mathrm{C}$. as soon as they were harvested. Within two hours the leaves were removed, cut as quickly as possible into pieces about $5 \mathrm{~mm}$. square and put into a flask of a freeze dryer actuated by a high-vacuum pump and suitable refrigerants. The temperature in the bulb was about $-30^{\circ} \mathrm{C}$. It took about eight hours to dry $11 \mathrm{gm}$. (fresh weight) of tomato leaflets. This operation was kindly performed for us by Mr. Zwar, of the Section of Plant Physiology of the Commonwealth Scientific and Industrial Research Organization. After eight hours, all but the last traces of water were removed and the material was transferred to screw-top bottles and stored (in the presence of air) in a deep-freeze at $-20^{\circ} \mathrm{C}$. After 36, 82 and 125 days of storage, portions of each sample were withdrawn suspended in buffer solution of $p \mathrm{H} 7.5$ made 0.01 molar in respect to sodium sulphite. Inocula prepared in this way were inoculated on to plants of tomato, tobacco and N. glutinosa by methods described in our previous papers. After storage for thirty-six and for eighty-two days, all inoculated plants became infected with the virus. The reaction of plants inoculated 125 days after harvesting showed that both strain $A$ and strain $E$ of tomato spotted wilt virus had survived; but there was some evidence that the mild strain $E$ is not holding out as well as strain $A$.

The tests are still in progress.

RUPERT J. Best

H. P. C. Gallus

Waite Agricultural Research Institute, University of Adelaide, South Australia. March 9.

${ }^{1}$ Bald, J. G., and Samuel, G., Coun. Sci.'Ind. Res. (Avstralia) Bull. 54 (1931).

${ }^{2}$ Best, Rupert J., and Samuel, G., Ann. App. Biol., 23, 509 (1936).

${ }^{3}$ Best, Rupert J., Aust. J. Exp. Biol. Med. Sci., 15, 191 (1937).

4 Best, Rupert J., Aust. J. Exp. Biol. Med. Sci., 17, 1 (1939) ; J. Aust. Inst. Agric. Sci., 5, 94 (1939).

s Best, Rupert J., and Gallus, H. P. C., Aust. J. Sci. (in the press).

\section{Causes of Coconut Nutfall and Gumosis}

$\mathrm{WAY}^{1}$ has reported that the coreid bug Theraptus sp. is the cause of nutfall and gumosis of coconuts in East Africa. During more recent investigations to discover economical methods of combating this pest, it has been found that Theraptus sp. is only one of at least four insect pests causing either nutfall or gumosis or both. The larvæ of the weevil Diocalandra frumenti $\mathrm{F}$. will cause both nutfall and particularly gumosis of immature nuts. Mansfield-Aders ${ }^{2}$ noted the presence of $D$. frumenti in coconuts in Zanzibar and suggested that it might be a cause of nutfall and gumosis. $D$. frumenti thrives best in areas infested by Theraptus sp. and Anoplolepis longipes Jerd. It is preyed upon by both Anoplolepis custodiens Smith and Ecophylla smaragdina L., var. longinoda Latr. The larvæ of the moth Lamoria sp. cause considerable nutfall in palms foraged by $A$. longipes and Pheidole sp. by boring into and eating the bases of the young nuts. A major cause of nutfall in areas where Theraptus sp., D. frumenti and Lamoria sp. have been either eradicated or controlled by insecticides is the ant Polyrhacis schistacea Gerst., vars. rugulosa Mayr and militaris $\mathrm{F}$. These ants nest both in the ground and in the palms, and feed mostly on pollen and nectar. They are so efficient at removing the nectar from flowering nuts that they remove the lining of the stigmata and prevent fertilization. In palms heavily foraged by Polyrhacis sp. complete loss of nuts occurs. 